\title{
Folkways and Stateways: Continuing Dilemmas of Housing, Race, and Place
}

\section{Clarence Lang}
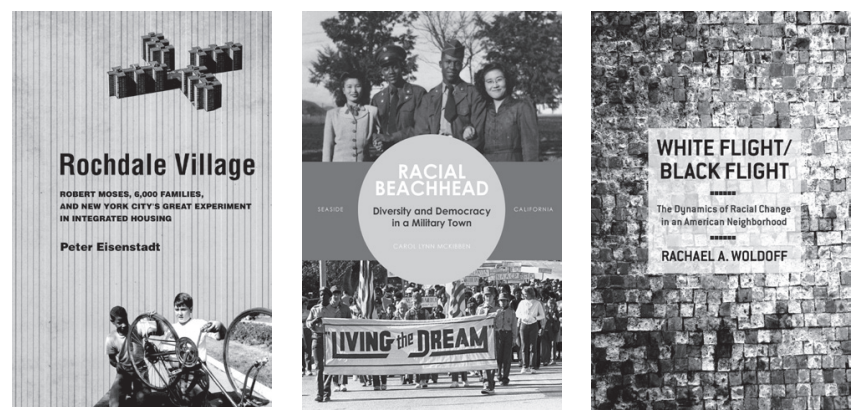

ROCHDALE VILLAGE: Robert Moses, 6,000 Families, and New York City's Great Experiment in Integrated Housing. By Peter Eisenstadt. Ithaca: Cornell University Press. 2010.

RACIAL BEACHHEAD: Diversity and Democracy in a Military Town-Seaside, California. By Carol Lynn McKibben. Stanford: Stanford University Press. 2012. WHITE FLIGHT/BLACK FLIGHT: The Dynamics of Racial Change in an American Neighborhood. By Rachael A. Woldoff. Ithaca: Cornell University Press. 2011. 
The collapse of the home mortgage system has left working- and middleclass Americans buried alive in the wreckage, but there may yet be a silver lining. If so, it is that the disaster provides policymakers and scholars an occasion to critically evaluate the inner workings of the private housing market, examine the effects of a deregulated financial services industry, reclaim forgotten social democratic legacies of cooperative housing, and call upon the federal government to rejuvenate its commitment to guaranteeing its citizens affordable, stable, and quality shelter. We potentially also have a teachable moment to again consider the tightly interwoven politics of housing and race. Indeed, the proliferation of subprime mortgages to people of color (which precipitated the larger housing crisis in the first place) illustrated that the issues of economic injustice embedded in predatory housing policies are entirely of a piece with unresolved matters of racial inequality. Housing has served as a powerful pivot for racial exclusion and its concomitant forms, including divergent educational opportunities, health dissimilarities, and a black/white wealth gap. ${ }^{1}$ If anything, the bursting of the housing market bubble has exacerbated racial wealth disparities, giving white households twenty times the net worth of black households and eighteen times that of Hispanic households. " "Of all policy areas of civil rights," argues sociologist Christopher Bonastia, "residential integration has the greatest potential to alter the racial landscape."

Conventional wisdom holds that government has no legitimate place "socially engineering" housing markets to pursue racial equality, but casual observers ignore government's long record of engagement on the opposite end. As scholars such as Bonastia, Arnold R. Hirsch, Thomas J. Sugrue, Robert O. Self, Colin Gordon, Wendell E. Pritchett, and George Lipsitz have documented, national, state, and municipal bureaucracies - from the Home Owners' Loan Corporation to the Federal Housing Administration and local public housing agencies - played an active role in sorting neighborhoods by race and class during the early twentieth century. ${ }^{4}$ Colluding with elected officials and white homeowners' associations, moreover, they helped protect and reinscribe residential segregation following World War II. As captured in the recent award-winning documentary film, The Pruitt-Igoe Myth, the consequence was a two-tiered, federally subsidized system of highway construction, suburban homeownership, and entitlements for whites; and urban renewal, public apartment tenancy, and means-tested welfare for African Americans. ${ }^{5}$ Regardless of the landmark U.S. Supreme Court rulings in Shelley v. Kraemer (1948) and Jones v. Mayer (1968), the passage of the 1968 Fair Housing Act, antidiscrimination measures by the Department of Housing and Urban Development during the late 1960s and early 1970s, and the dramatic growth of minority homeownership in recent decades, government has intervened in the housing industry mainly to buttress the "hypersegregation" of residential space. ${ }^{6}$ Efforts to racially democratize housing, in contrast, have been largely short-lived and piecemeal. Relative to employment and schools, they also remain the least studied as a civil rights topic.? 
Thankfully, new civil rights scholarship has brought attention to 1960s-era open housing movements, especially in the North where residential apartheid was an especially violent battlefront of black freedom struggle. ${ }^{8}$ As this review essay discusses, other recent works have diverged from the focus on restrictive covenants, mortgage redlining, exclusionary zoning, racial steering, blockbusting, and mob action. Specifically, they have challenged the idea that residential discrimination has been uniformly intractable during the postwar period, or that racially integrated communities have been negligible. Some scholars have used historical narrative to redeem the federal government's record of championing residential integration, while others have looked beyond "white flight" to capture the dynamics of neighborhood transition. Taken together, these projects combine the methods of history, sociological inquiry, and even flashes of memoir. Although these works do not disprove the durability of housing discrimination over time, they do add more texture and nuance to ongoing conversations about the dilemmas of housing, race, and place. Given the exigencies of our contemporary moment, this recent scholarship also presents new possibilities for approaching housing policy — and housing reform - as a means for democratic participation, economic justice, and interracial comity.

As historian Peter Eisenstadt documents in Rochdale Village: Robert Moses, 6,000 Families, and New York City's Great Experiment in Integrated Housing, the movement for nonprofit housing held this very promise. Under the stewardship of Jewish labor radical Abraham Kazan, the United Housing Foundation (UHF) became New York City's largest builder of cooperative housing between the early 1950s and early 1970s, producing more than 33,000 apartments during its heyday. Rochdale Village, located in Jamaica, Queens, emerged as the most ambitious example of the UHF's utopian vision of attractive, affordable working-class housing and communally oriented living. Opened in 1963, it had the distinction of being not only the world's largest housing cooperative, but also the most expansive integrated development in New York City and perhaps even the nation. Composed primarily of Jewish wage-workers and upwardly mobile middle-class African Americans, Rochdale experienced a vibrant interracial "rough-and-tumble democracy" characterized as much by the class differences among black residents as by the ambivalent relations between black and white tenants (117). But as the author details, the entire experiment lasted only until the late 1960s, when white residents began departing in large numbers, leaving a shrinking population of elderly whites. Rochdale's occupancy became predominantly black.

Eisenstadt suggests that the seeds of white abandonment were planted in the contradictory circumstances surrounding the project's development. As much as Rochdale Village was Kazan's brainchild, it was also the product of an unlikely partnership with New York's formidable "master builder," Robert Moses, an outspoken civil rights opponent who had nationally popularized urban renewal schemes uprooting black communities. ${ }^{9}$ He had also wielded his considerable influence to defend the exclusion of African Americans from the Stuyvesant 
Town development - which, as historian Martha Biondi recounts, instigated local civil rights activism around fair housing. ${ }^{10}$ Moses was, nevertheless, a steely pragmatist, and he viewed the construction of Rochdale as a deterrent to middle-income flight from Gotham to the growing suburbs. Despite his antipathy toward desegregation, he was also willing to resign himself to a project of mixed-race housing because it embodied, in Eisenstadt's summation, "integration freely entered into by all parties, uncoerced, unmonitored, and unregulated" by government (80). Through Rochdale, moreover, Kazan as well as Moses hoped to affirm the continued viability of superblock-style housing, a model that had become passé among an emergent wave of urbanists attracted to the unplanned streetscapes and old-neighborhood preservation advocated by Jane Jacobs. ${ }^{11}$

However, locating Rochdale Village in the black middle-class enclave of South Jamaica stirred unease among homeowners who, facing an in-migration of poorer African Americans to the neighborhood, viewed Rochdale as another harbinger of displacement. At the time, moreover, black freedom organizations across the North were militantly protesting the racist practices of building trade unions. Consequently, Rochdale's construction, which continued longstanding patterns of job discrimination against black workers, became the focus of one of "the largest mass civil rights protests ever seen in New York City" (83). Paradoxically, Eisenstadt notes, the new Rochdale residents included many Jewish veterans of the Old Left, who over time helped foster the growth of black political power in southeastern Queens. Even still, he concludes, the siting of a predominantly white cooperative community within a virtually all-black neighborhood became an increasing source of strain. This was particularly the case in the wake of the bitter 1968 Ocean Hill-Brownsville crisis, during which black and Puerto Rican demands for community-run schools collided with white teachers' determination to protect their collective bargaining rights. Given the composition of New York City's teachers union, the conflict exacerbated black-Jewish tensions and symbolically discredited integration as a legitimate social goal. ${ }^{12}$

Rochdale's nadir deepened amidst the labor strife between the tenants and unionized maintenance workers and security guards, as well as many residents' growing anxieties about black urban crime. Then, too, New York's transition from an aspiring social democratic city to a neoliberal metropolis, beginning in the mid-1970s fiscal crisis, cast into disrepute the very idea of limited-equity cooperatives (David Harvey describes the national and global significance of New York City's neoliberal turn in succinct yet heartbreaking detail in A Brief History of Neoliberalism. $)^{13}$ By then, both Kazan and the UHF had passed away. Rochdale Village remained, and after the 1980s experienced a renaissance as an exemplar of black cooperative institution building. But while some black middle-class families were able to seek homes outside southeastern Queens, Rochdale's continued existence, among other things, spoke to the constrained housing options that even upwardly mobile African Americans have continued to confront (221). 
By his own admission, though, the author is more interested in the housing development's brief interracial heyday in the ' 60 s, which stems in great measure from his own youth as a resident there from 1964 to 1973. This personal background lends the book uncommon poignancy. Yet, the zenith of Rochdale Village's "interracial" period might more accurately be understood as "biracial," since by Eisenstadt's description, the social interactions there were predominantly intraracial, with black and white residents sharing neither dense nor multiple associations. Even when viewed in the most sympathetic light, further, the reader is drawn to the judgment that Rochdale, at its best, was little more than an oasis within a larger housing market whose actors have remained devoted to the color line. This is not to say that Eisenstadt waxes nostalgic for a halcyon past that never existed. Ultimately, he brings Rochdale's tumultuous history to bear in contemplating the immediacy of the present:

We again need to ask, with Abraham Kazan, whether a necessity as basic as housing should or in the end can rest on the shaky foundations of ferociously speculative real estate market. And the question is not whether we can afford to build more limited equity cooperatives but whether we can afford not to. There has never been a better time than now to once again start building Abraham Kazan's cooperative commonwealth. His original vision . . . is badly missed in the hyper-capitalist city and housing market of the early twenty-first century. (248)

As historian Carol Lynn McKibben delves, however, a far more successful model of integrated housing exists not in large urban areas, but rather in smaller cities attached to military bases. It was in military towns, she argues in Racial Beachhead: Diversity and Democracy in a Military Town-Seaside, California, where the federal government's capacity for bolstering racially mixed neighborhoods materialized most fully, "far surpassing anything that was going on in the rest of America" (78). Particularly in Seaside, residents "created a new politics of inclusion and a commitment to place that effectively ... serves as a reminder that integration can work to make change in ideas about race" (14).

Initially emerging as a working-class immigrant settlement in an undeveloped portion of California's Monterey Peninsula, Seaside attracted a surge of racial minorities first during the Depression years and then during the Second World War as the area received an infusion of military spending. Nestled between Fort Ord and the peninsula's upscale resort communities, the City of Seaside had the region's most diverse population by the time it was incorporated in 1954. As the armed forces desegregated in the years following President Harry S. Truman's Executive Order 9981, and responding to directives from the highest echelons of the military, Fort Ord became the first U.S. base to implement complete integration, setting the tempo for race relations off base as well. Indeed, Seaside 
housed "a critical mass of soldier families, most black," McKibben writes, "but also Asians, white, and multiracial, many of whom were career personnel" (5).

Seaside was no more of a racial utopia than New York's Rochdale Villagein fact, racism was as pervasive here as throughout California and elsewhere, according to the author. Nonetheless, Fort Ord's black employees formed the bedrock of an economically secure black middle class that, through multiracial partnerships, pursued a civil rights agenda in employment, education, and local electoral politics. In this respect, Seaside mirrored the historical particularities of California "where multiple communities of color lived side-by-side in ways that they did not in most eastern and Midwestern cities and towns in the early half of the twentieth century" (4). As historians such as Gerald Horne, Scott Kurashige, and Mark Brilliant have demonstrated, this spatial closeness created interactions that ran the gamut from conflict and indifference to parallel activities and moments of cooperation. ${ }^{14}$ With regard to housing, "it was far easier in Seaside than in other California towns and cities to develop plans for redevelopment that did not focus on relocating blacks, Latinos, or other minority groups or on building large public housing complexes but on investing in and improving what already existed" through low-interest loans and similar mechanisms of preservation (122).

To the extent that the City of Seaside was exceptional in its integrated housing markets, however, racially exclusive housing policies prevailed via regional planning. Specifically, the city was marginalized among the predominantly white, more affluent municipalities of the Monterey Peninsula. This became the case especially between the 1970s and 1990s, when African Americans emerged as the most influential group in Seaside's political and cultural life. "As long as Seaside was associated with African Americans and with the military," McKibben explains, "its efforts at boosterism and development were thwarted by racism that was pervasive and embedded in the American psyche, and in everything from politics to economics to infrastructure" (209).

The closure of Fort Ord in the early 1990s further fed this isolation and economic decay, and it accompanied the rapid growth of a new, non-military Mexican immigrant population, as well as the search for a new post-military identity. To integrate themselves more fully into regional growth schemes, Seasiders were compelled to adopt an identity that conformed to a vision that was "increasingly both whiter and more Hispanic," which fostered a backlash against African American political affinities (233). This has reflected a broader dynamic in which many cities in California and around the nation have had to "come to terms with a new identity as a minority-majority Latino city" (266). McKibben maintains that in contrast to other communities, though, Seaside's demographic transition has been largely without open conflict and violence - due in large part, she argues, to a legacy of multiracialism and inclusion shaped over decades of military presence.

The book makes a compelling case against the idea that the federal government was, in all cases and at all times, a culprit in housing discrimination. Consistent with the work of Brilliant and others, Racial Beachhead also con- 
tributes to widening the civil rights narrative through its depiction of multiracial movement work encompassing African Americans, Asians, and Latinos, as well as the fault lines among them. Likewise, McKibben's latter chapters answer a challenge, posed by Kenneth Kusmer and other urban historians, to "evaluate the impact of emergent multiracial (as opposed to multiethnic) cities on African American communities and race relations.. ${ }^{15}$ Nonetheless, the book suffers from a narrow interpretation of black protest, one that too easily defines integrationist methods as "more measured and careful" than the presumably reckless black power politics of the late 1960s and early 1970s (146). The author's framing of the issue could have been better informed by recent trends in Black Freedom Studies scholarship, which have treated civil rights and black power in more complicated ways. ${ }^{16}$

More fundamentally, Racial Beachhead veers toward overstatement in depicting the military as a beacon of racial tolerance. It is true that the military functioned as a pathway to black economic opportunity and respectability after 1945, while the armed forces indeed became one of the nation's most integrated institutions. With self-conscious hyperbole, historian Orville Vernon Burton has even gone so far as to describe military installations as "a kind of heartland of socialism, providing government-run single-payer health care, pensions, day care, education, job training, antidiscriminatory housing," and other social democratic provisions. ${ }^{17}$ Yet, how meaningfully can we generalize from an example like Seaside, particularly when comparing its population and housing practices with those surrounding military bases in the South, for example, where the racial kinetics differed from the West Coast? As labor scholar Kimberley L. Phillips suggests in her own recent work, even where base commanders possessed the will, they did not necessarily wield the power to affect race relations off base. ${ }^{18}$ A further dilemma, Phillips notes, has been the military's role in reifying racial hierarchies at home and abroad, even as the military personnel itself integrated. The point is that McKibben has raised an intriguing scholarly question that begs further study and that hopefully will yield greater comparative examination. In any case, as with Rochdale Village, one is left with the impression that Seaside at its rosiest was an exception that proved the rule of housing discrimination.

Relative to Eisenstadt, however, McKibben is more attentive to the postintegration dynamics of black residential life. Black settlement in Seaside seemed consistent with patterns of black suburbanization prior to $1950^{19}$; and while African American migration from inner cities to urban fringes and suburbs have increased in recent years, white flight has also endured as a response. As a result, black suburbanites have found themselves similarly excluded, economically disadvantaged, and abandoned. ${ }^{20}$ Yet, both developments - black out-migration from central cities and white flight-are more complex than scholars have presented them, argues sociologist Rachael A. Woldoff. In White Flight/Black Flight: The Dynamics of Racial Change in an American Neighborhood, she contends that commentators cannot fully understand white flight and its effects without comprehending what occurs after white residents depart a community. "Whereas 
white flight marks the end of an era for those who leave," she writes, "it is just the beginning for the newcomers and old-timers who choose to remain" (213). Unfortunately, few have made this a scholarly point of departure. ${ }^{21}$

Scrutinizing the outer-ring urban community of "Parkmont," Woldoff considers two groups that remained following white flight: elderly white "stayers" who have actively chosen to "age in place," and stably employed black "pioneers." Rather than creating rancor, their exchanges have fostered an ethos of mutual support, with black neighbors providing caregiving assistance and companionship, and the "stayers" tutoring them in community history and norms. In practical terms, this has simultaneously bolstered white elderly residents' autonomy and preserved some measure of continuity in neighborhood identity. What this arrangement means from the standpoint of race relations is less clear-though, as the author reasonably concludes, the fact that black "pioneers" willingly chose to move to a once exclusively white community, and white "stayers" have remained in place, despite having the financial means to leave, indicates the malleability of racial attitudes. "Neighborhood change can, at least temporarily," she asserts, "open opportunities for friendship that cross the lines of race, age, and ethnicity, contributing to a stronger community" (218). Resonating with Eisenstadt's description of elderly whites and middle-class blacks cohabiting at Rochdale Village after the late 1960s, Woldoff delineates the conditional nature of white antipathy and flight in "Parkmont." That is, the evidence suggests that aging whites, having reared children and invested memories in place, are much likelier than younger white families to stay in their households during and after the racial composition of a community has changed.

Woldoff adds to her discussion a third group of actors: a black "second wave" whose members have arrived since white flight, many of them having newly achieved homeownership through subprime mortgages. Holding weaker ties than white "stayers," regarded apprehensively by their black "pioneer" predecessors, and relatively poorer than the others, the "second wavers" are perceived by both groups as the source of rapid housing turnover, disorderly public behavior, school misconduct, and rising neighborhood crime. From the perspective of the more settled white and black residents, the newcomers' presence has contributed to irregular services and infrastructure maintenance, the disintegration of the commercial district, and an overall erosion of residential stability and social cohesion. In an ironic twist, many African American "pioneers" - earlier derided by fleeing whites — now find themselves closely aligned with their white neighbors in a shared rebuke of other black newcomers. This interplay between the two waves of black residents is significant for Woldoff, in that "their shared culture and historical experience of racial exclusion cannot bridge their more proximate conflicts over social and community values in their new neighborhood," conditioning a paradoxical "black flight" among those with the means to leave (6).

In this sense, White Flight/Black Flight underscores recent interventions by such scholars as Mary Pattillo, Karyn R. Lacy, Preston H. Smith II, Will 
Cooley, and others who have approached housing as not only a focal point of racial formation between whites and African Americans, but also as a site of class stratification among black people themselves. ${ }^{22}$ Presenting interviews with select "Parkmont" locals lends power to Woldoff's arguments, though at times she too easily accepts the black pioneers' normative judgments of the second wave. Nor does she critically interrogate the elusive "values" that supposedly separate the newcomers from long-time residents. This implicitly situates the working-class poor outside mainstream conventions. Yet, couldn't the newcomers' risky pursuit of homeownership, for instance, reckon as proof of their desire for middle-class respectability? As the author herself acknowledges, what on the surface appears to be a lack of communal esprit de corps on the part of the "second wavers" actually stems from a disinvestment in schools, garbage collection and other public infrastructure, an economic marginality that leaves many newcomers struggling to pay mortgages much less make costly home repairs, and dislocation and trauma among black second wave youth. Not surprisingly, Woldoff eventually argues for a holistic model of community rejuvenation through promoting neighborhood voluntarism to address quality-of-life issues and deter serious crime, revitalizing local business districts - and, most importantly, encouraging fair housing practices, including protections from predatory loans and foreclosure abatement programs. As her proposed remedies make clear, white suburbanization and residential exclusion have been a crucial component of a more figurative "white flight" from liberal distributive social policy to-in American Studies scholar George Lipsitz's description - a stance of "hostile privatism and defensive localism."23

And here is the rub. Notwithstanding the highly contingent aspects of housing discrimination explored in these three books, white racial exclusion emerges in all of them as the decisive element shaping residential life. A planned cooperative housing environment like Rochdale Village does not, by itself, beget positive race relations, let alone racial equality. By the same token, the alternative to superblock developments, proposed by critics like Jane Jacobs, at times resulted in neighborhood gentrification that undercut the very diversity and affordability she championed. Tragically, Eisenstadt notes, "the subsequent half century has demonstrated that America can make racial progress in some areas - even elect a black president - without seriously challenging the prevailing segregation of our neighborhoods and schools" (131). As each of these works manifests, the factors underlying persistent housing discrimination are much larger than civic folkways and racial sentiments among the citizenry. Instead, they are trumped at the macro level by governmental stateways even if, as McKibben suggests, the government bureaucracy consists of numerous contending parts.

These issues aside, Eisenstadt, McKibben, and Woldoff all illuminate new pathways of inquiry in the study of housing and race, including the lessons of cooperative housing as a proven alternative to market-based solutions; the uneven legacies of integration in military towns; comparative treatments of housing discrimination against racial/ethnic and immigrant groups, as well as their diverse 
patterns of residential life $\mathrm{e}^{24}$; and the prospects for securing the long-term health of racially transitioning communities. Along these lines, additional scholarship is necessary to identify the relationship between black suburbanization and white central-city gentrification, and how these dual developments reflect the shifting spatial locations of concentrated poverty and reinvestment in metropolitan regions. We need more research, as well, on the traditions of independent black planning and development that have enabled African American communities to withstand the burden of racial exclusion in urban and suburban communities alike. ${ }^{25}$

Other scholars have called for jettisoning the city-suburb dichotomy altogether, recognizing how racial minorities' experiences at a broader, metropolitanwide level have included "affluent single-family neighborhoods, high-poverty inner-ring suburbs, various types of new immigrant gateways, majority-minority counties ... and exurban developments hit hard by predatory subprime lending and the ongoing home foreclosure crisis. ${ }^{26}$ Even when residential discrimination has relegated middle-income and poor African Americans to the same neighborhoods, further, their attitudes about this close proximity have diverged. Hence, black middle-class neighbors' attempts to demarcate themselves from their working-class analogues, in communities like South Jamaica, Queens, "Parkmont," and elsewhere, are another subject deserving further attention.

We also are likely to see more work on the recent subprime mortgage disaster, conditioned by decades of racially segmented housing affecting black people across class lines. Whereas African Americans were once systematically denied mortgage financing, many now experience the opposite extreme, systematically exposed to higher-rate loans than white borrowers. In light of this catastrophe, more policymakers and scholars should heed Woldoff's recommendation to review the effectiveness of the Fair Housing Act and include additional protections in the law. ${ }^{27}$ Popular understandings of "residential integration," too, need fuller elaboration, not least of all because its meanings have been heavily contested even among its advocates. For some proponents, it was a means of legitimizing liberal identities and political action in the larger world; for others, it was an actual lived experience at the neighborhood level and a route to tangibly improving material conditions. ${ }^{28}$

Finally, the literature will benefit from greater cross-fertilization among historians and social scientists working on housing discrimination and protest movements, respectively. Good examples of this include Lipsitz's work on the "Black spatial imaginary," and political scientist Todd C. Shaw's research on black grassroots mobilization, urban regimes, and community-housing initiatives in Detroit. ${ }^{29}$ The recent post-collapse lawsuits against JP Morgan Chase, Wells Fargo, Morgan Stanley, and other financial institutions involved in predatory mortgage loans targeting African American borrowers, highlights what such connections might accomplish in practice, and the need for greater public controls on financial capital. It shows too that studying housing policy in tandem with 
reformist struggles can reveal much to scholars. To be sure, there is no singular method of democratizing housing opportunity, but the end game should be livable neighborhoods of opportunity for all, regardless of whether or not people of color reside next door to whites. Moreover, in the absence of sustained movements against institutional racism, deregulation, and fiscal austerity - coupled with the sanctions and incentives of an interventionist federal state-short-lived experiments in integrated living are likely to remain merely that.

\section{Notes}

1. Melvin Oliver and Thomas Shapiro, Black Wealth/White Wealth: A New Perspective on Racial Inequality, second edition (New York: Routledge, 2006). For viewpoints centering educational policies in the shaping of housing markets, see Matthew D. Lassiter's guest edited special section on "Schools and Housing in Metropolitan History," Journal of Urban History 38 (March 2012).

2. Rakesh Kochhar, Richard Fry, and Paul Taylor, "Twenty-to-One: Wealth Gaps Rise to Record Highs Between Whites, Black and Hispanics," Pew Social \& Demographic Trends, July 26, 2011. www.pewsocialtrends.org/2011/07/26/wealth-gaps-rise-to-record-highs-between-whitesblacks-hispanics/.

3. Christopher Bonastia, Knocking on the Door: The Federal Government's Attempt to Desegregate the Suburbs (Princeton: Princeton University Press, 2006), 164.

4. Bonastia, Knocking on the Door; Arnold R. Hirsch, Making the Second Ghetto: Race and Housing in Chicago, 1940-1960 (1983; rprt., Chicago: University of Chicago Press, 1998); Thomas J. Sugrue, The Origins of the Urban Crisis: Race and Inequality in Postwar Detroit (Princeton: Princeton University Press, 1996); Robert O. Self, American Babylon: Race and the Struggle for Postwar Oakland (Princeton: Princeton University Press, 2003); Colin Gordon, Mapping Decline: St. Louis and the Fate of the American City (Philadelphia: University of Pennsylvania Press, 2008); Wendell E. Pritchett, Robert Clifton Weaver and the American City: The Life and Times of an Urban Reformer (Chicago: University of Chicago Press, 2008); and George Lipsitz, How Racism Takes Place (Philadelpha: Temple University Press, 2011). See also Kenneth L. Kusmer and Joe W. Trotter, eds., African American Urban History Since World War II (Chicago: University of Chicago Press, 2009) DVD.

5. The Pruitt-Igoe Myth: An Urban History (Dir. Chad Freidrichs, First Run Features, 2011).

6. For a seminal theorization of "hypersegregation," see Douglas S. Massey and Nancy A. Denton, American Apartheid: Segregation and the Making of the Underclass (Cambridge, MA: Harvard University Press, 1993).

7. Bonastia, Knocking on the Door, 20.

8. See, for example, Patrick D. Jones, The Selma of the North: Civil Rights Insurgency in Milwaukee (Cambridge, MA: Harvard University Press, 2009); Martha Biondi, To Stand and Fight: The Struggle for Civil Rights in Postwar New York City (Cambridge, MA: Harvard University Press, 2003); and Thomas J. Sugrue, Sweet Land of Liberty: The Forgotten Struggle for Civil Rights in the North (New York: Random House, 2008).

9. See Robert A. Caro, The Power Broker: Robert Moses and the Fall of New York (New York: Knopf, 1974).

10. Biondi, To Stand and Fight, 121-36. 1961).

11. See Jane Jacobs, The Death and Life of Great American Cities (New York: Vintage Books,

12. For a book-length treatment of this conflict, see Jerald E. Podair, The Strike That Changed New York: Blacks, Whites, and the Ocean Hill-Brownsville Crisis (New Haven: Yale University Press, 2002).

13. David Harvey, A Brief History of Neoliberalism (New York: Oxford University Press, 2005), 45-48. See also Joshua B. Freeman, Working-Class New York: Life and Labor Since World War II (New York: The New Press, 2000).

14. Gerald Horne, Fire This Time: The Watts Uprising and the 1960s (Charlottesville: University Press of Virginia, 1995); Scott Kurashige, The Shifting Grounds of Race: Black and Japanese Americans in the Making of Multiethnic Los Angeles (Princeton: Princeton University Press, 2008); and Mark Brilliant, The Color of America Has Changed: How Racial Diversity Shaped Civil Rights Reform in California, 1941-1978 (New York: Oxford University Press, 2010). See also Josh Sides, L.A. City Limits: African American Los Angeles from the Great Depression to the Present (Berkeley: University of California Press, 2003).

15. Kenneth L. Kusmer, "African Americans in the City since World War II: From the Industrial to the Post-Industrial Era,” Journal of Urban History 21 (May 1995): 490. 


\section{Clarence Lang}

16. For examples of recent survey essays on the field, see Jeanne Theoharis, "Black Freedom Studies: Re-imagining and Redefining the Fundamentals," History Compass 4 (March 2006): 34867; Sundiata Keita Cha-Jua and Clarence Lang, "The 'Long Movement' as Vampire: Temporal and Spatial Fallacies in Recent Black Freedom Studies," Journal of African American History 92 (Spring 2007): 265-88; and Peniel E. Joseph, "The Black Power Movement: A State of the Field," Journal of American History 96 (December 2009): 751-76.

17. Orville Vernon Burton, "The South as 'Other,' the Southerner as 'Stranger,"' Journal of Southern History 79 (February 2013): 12.

18. Kimberley L. Phillips, War! What Is It Good For?: Black Freedom Struggles and the U.S. Military from World War II to Iraq (Chapel Hill: University of North Carolina Press, 2012).

19. See Andrew Wiese, Places of Their Own: African American Suburbanization in the Twentieth Century (Chicago: University of Chicago Press, 2004).

20. See, for instance, Cheryl L. Reed and Monifa Thomas, "Blacks Hurt by Gap in Home Values," Chicago Sun-Times, November 13, 2005, A20; and Monifa Thomas, "Suburbs No Guarantee of Opportunity: Affluent Blacks Leaving the City Tend to Cluster in Just a Few Communities, but May Offer Limited Economic Benefits or Access to Good Schools, Jobs," Chicago Sun-Times, November 15, 2005. See also Jennifer Hamer, Abandoned in the Heartland: Work, Family, and Living in East St. Louis (Berkeley: University of California Press, 2011).

21. For an exception, see Will Cooley, "Moving Up, Moving Out: Race and Social Mobility in Chicago, 1914-1972," Ph.D. Dissertation, University of Illinois at Urbana-Champaign, 2008.

22. See, for example, Mary Pattillo-McCoy, Black Picket Fences: Privilege and Peril Among the Black Middle Class (Chicago: University of Chicago Press, 1999); Mary Pattillo, Black on the Block: The Politics of Race and Class in the City (Chicago: University of Chicago Press, 2007); Karyn R. Lacy, Blue-Chip Black: Race, Class, and Status in the New Black Middle Class (Berkeley: University of California Press, 2007); Preston H. Smith II, "The Quest for Racial Democracy: Black Civic Ideology and Housing Interests in Postwar Chicago," Journal of Urban History 26 (January 2000): 131-57; Preston H. Smith II, Racial Democracy and the Black Metropolis: Housing Policy in Postwar Chicago (Minneapolis: University of Minnesota Press, 2012); and Will Cooley, "Moving On Out: Black Pioneering in Chicago, 1915-1950," Journal of Urban History 36 (July 2010): 485-506.

23. Lipsitz, How Racism Takes Place, 15. For further discussion of this theme, see Kevin M. Kruse, White Flight: Atlanta and the Making of Modern Conservatism (Princeton: Princeton University Press, 2005); and Matthew D. Lassiter, The Silent Majority: Suburban Politics in the Sunbelt South (Princeton: Princeton University Press, 2006).

24. As an example, see Wendy Cheng, "The Changs Next Door to the Diazes: Suburban Racial Formation in Los Angeles's San Gabriel Valley," Journal of Urban History 39 (January 2013): 15-35. Cheng's article appeared as part of a special section in this issue co-edited by Matthew D. Lassiter and Christopher Niedt on the theme of "Suburban Diversity in Postwar America."

25. Charles E. Connerly, "The Most Segregated City in America": City Planning and Civil Rights in Birmingham, 1920-1980 (Charlottesville: University of Virginia Press, 2005).

26. Matthew D. Lassiter and Christopher Niedt, "Suburban Diversity in Postwar America," Journal of Urban History 39 (January 2013): 3. Legal scholar john a. powell further complicates this theme of metropolitan diversity and housing discrimination by identifying "regional differences in the preponderance of within-city, between city and suburb, and within-suburb segregation. Segregation between blacks and other groups occurs more often across city line in the Midwest and Northeast; it is largely due to within-suburb segregation in the West; and in the South, within-city segregation and within-suburb segregation contribute equally to the overall metropolitan segregation level." john a. powell, "Reflections on the Past, Looking to the Future: The Fair Housing Act at 40," Indiana Law Review 41 (2008): 611.

27. See also powell, "The Fair Housing Act at 40," 616.

28. See the special section, "Reimagining Integrated Space in Post-WWII Philadelphia," edited by Abigail Perkiss in Journal of Urban History 38 (May 2012).

29. Lipsitz, How Racism Takes Place, 18-20; and Todd C. Shaw, Now Is the Time!: Detroit Black Politics and Grassroots Activism (Durham: Duke University Press, 2009). 


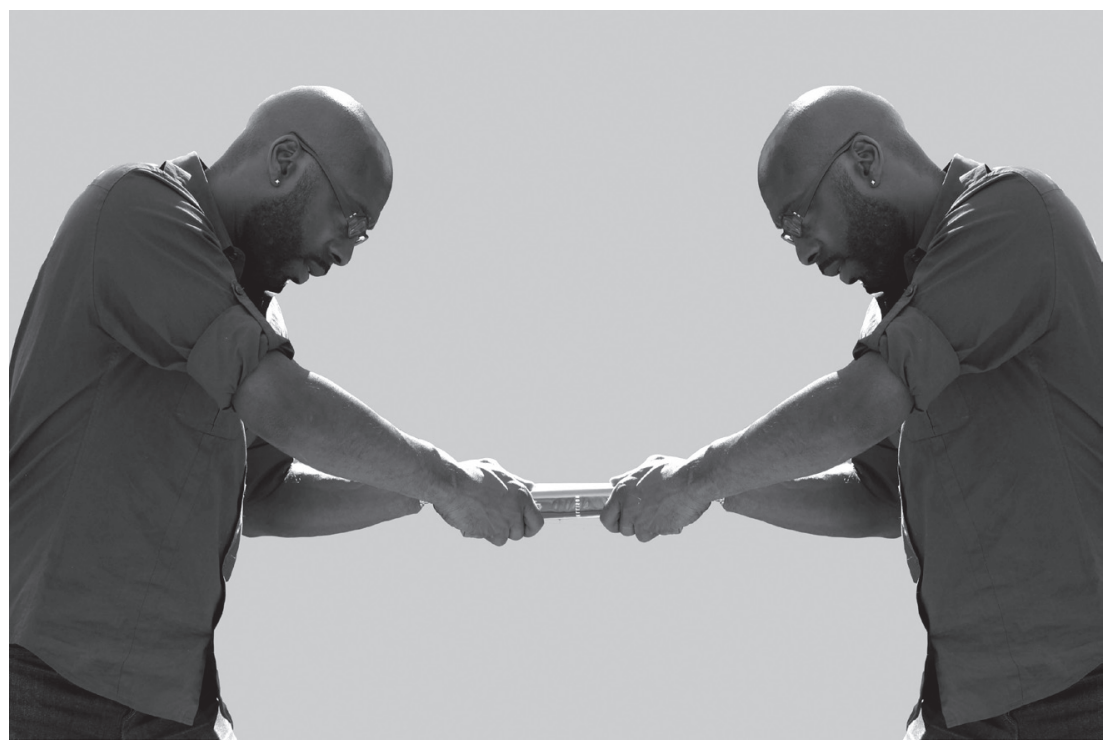

AMSJ editorial board member Davarian Baldwin

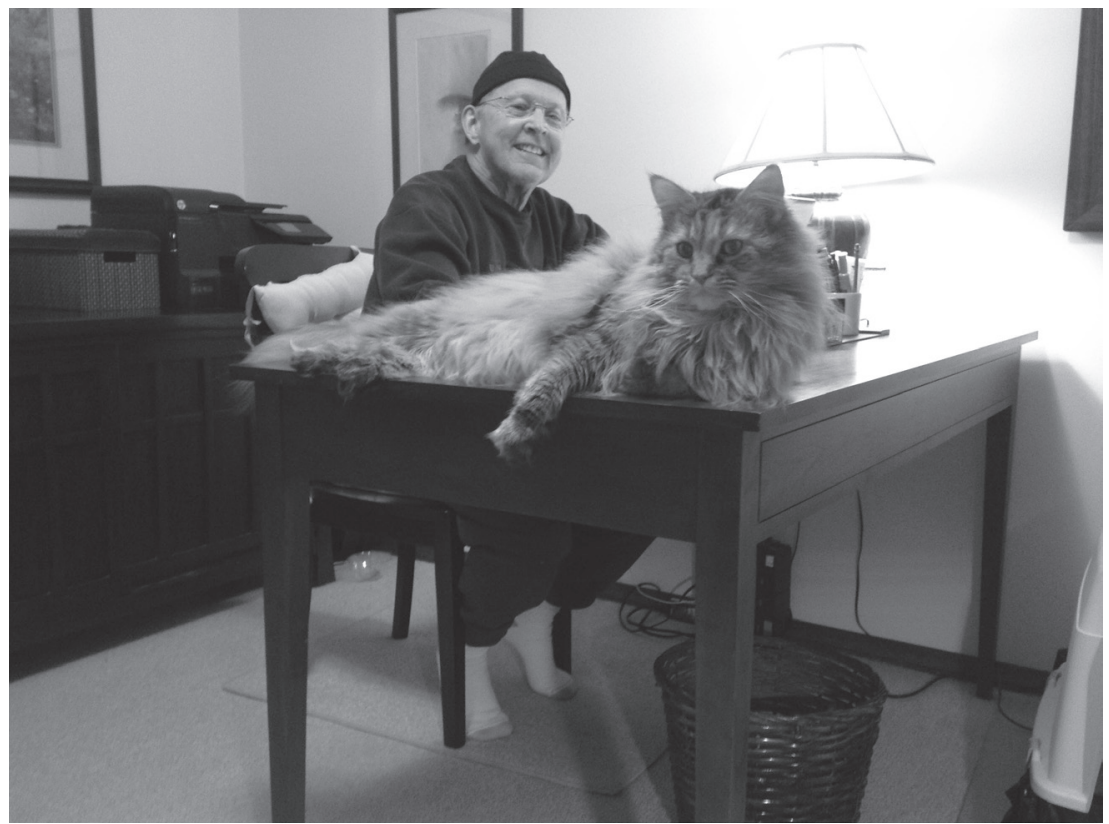

AMSJ editorial board member J. Robert Kent 
